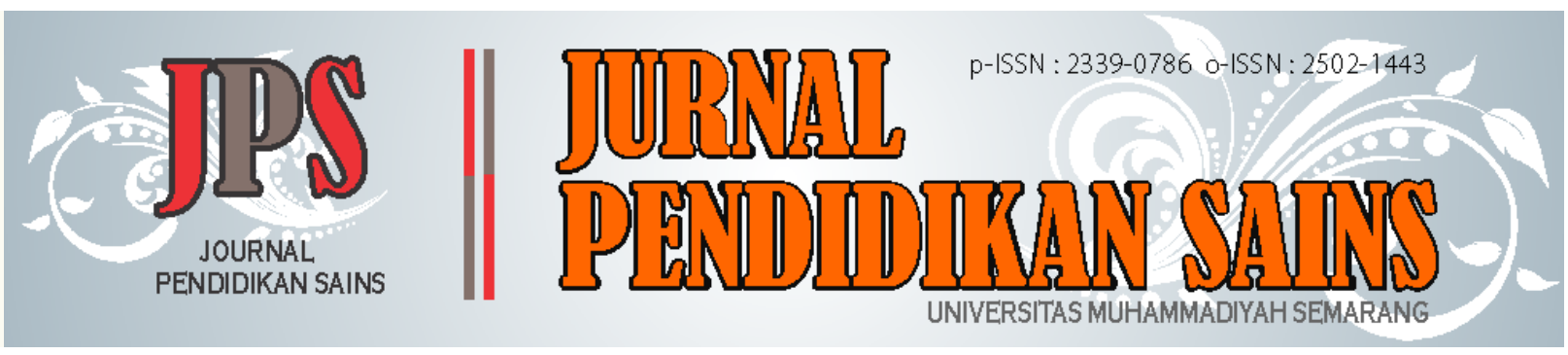

\title{
Exploration Of Students' Argumentation Skill Assisted Format Representation In Solving Electrical Concept
}

\author{
Rikardus Feribertus Nikat ${ }^{1, *}$, Algiranto $^{, 2}$, Luis Valera ${ }^{3}$ \\ 1.2 Department of Physics, Musamus University, Merauke Papua, Indonesia \\ ${ }^{3}$ Department of Physics, Instituto Superior Cristal Dili, East Timor \\ * Corresponding author: nikat_fkip@unmus.ac.id
}

\begin{tabular}{|c|c|c|}
\hline Article histo & & Abstract \\
\hline Submission & :2020-12-30 & \multirow{5}{*}{$\begin{array}{l}\text { The argumentation skill is one of the supporting abilities in determining the } \\
\text { quality of thinking in the revolution } 4.0 \text { era. The development of argumentation } \\
\text { skills is essential to solving physics problems, especially in exploring how they } \\
\text { solve problems and understand concepts so that misconceptions do not occur. } \\
\text { This study aims to determine the improvement of students' argumentation skills } \\
\text { in solving electrical concept problems before and after the intervention. This } \\
\text { type of research uses a mixed-method model research method with an } \\
\text { embedded experimental design. The research subjects consisted of } 32 \text { pre- } \\
\text { service students of the Department of Physics Education at Musamus } \\
\text { University who had or are currently taking the magnetic electricity course. The } \\
\text { results showed that students' argumentation skills improved along with the help } \\
\text { of worksheets assisted with representation formats during lectures. }\end{array}$} \\
\hline Revised & : 2021-02-16 & \\
\hline Accepted & : 2021-03-08 & \\
\hline \multicolumn{2}{|l|}{ Keyword } & \\
\hline \multicolumn{2}{|c|}{$\begin{array}{l}\text { Student Argumentation Skill } \\
\text { Format Representation } \\
\text { Electrical concept }\end{array}$} & \\
\hline
\end{tabular}

\section{INTRODUCTION}

The Argumentation skill is the ability of an individual to collaborate or respond the statements through scientific and sensible procedures. One of the indicators of its achievement is individuals should be able to implement argumentation skills to support critical thinking skills, creative thinking, and problem-solving in their daily activities (Trilling and Fadel, 2009). Argumentation is vital to collaborate individual actions to improve an individual's decision-making skills (Öztürk \& Doğanay, 2019), solve problems, and claim an allegation based on authentic facts or evidence (Iwuanyanwu, (2019). In the context of physics learning, the argumentation skill is crucial to evaluate the understanding of concepts, concept changes and solve physics problems (Viyanti et al., 2016). One of the most prominent examples is the strengthening of oral and written form argumentation in explaining the meaning of physical physics, a physical phenomenon, both at the lower-order thinking skill (LOTS) level and higher-order thinking skill (HOTS) (Viyanti. et al., 2020). In this case, the use of argumentation in explaining the concept of physics is not only a compliment but as the main bridge in creating a new thought. Individuals must have the skill to represent concepts that will be very helpful to students in scientific arguments in solving problems of physics (Bahri, 2012). In its evaluation, the development of argumentation capability instruments can refer to five indicators adapted to the field of physics, namely: claims, data, qualifiers, warrants, and backing (Cari. et al., 2019)

Based on the current conditions in pre-service students in the department of Physics Education Musamus University who have studied fundamental physics or magnet and electricity topic. Some difficulties are solving the physics problems, especially in terms of explaining the basic concepts of physics. It is obtained based on the cognitive assessment of students' learning related to concept problems more minor than the maximum. Some of the contributing factors are as follows:1) students have $60 \%$ limitations in cognitive skills to analyze and interpret basic concepts of physics. Some students only 
choose the mathematical completion format. 2) They have not a good experience exploring abstract physics concepts. The abstract concept of physics has not been explored to the maximum. They must have a strong knowledge of elementary physics concepts not to be confused when delivering to their students. 3) Students are used to solving LOTS-level physics problems. According to the correct concept, the students who have studied fundamental physics can only $25 \%$ can give reasons for each answer. Sinaga (2014) explained that students have difficulty translating abstract concepts into visualizations of real things. These habits have an impact on students' confusion and problems when solving on HOTS levels problems. 4) More than $80 \%$ of students had misconceptions. Misconceptions in physics education students can impact their competence as an educator in transferring knowledge to their students. 5) The assessment model in physics lectures has not accommodated concept or mathematical problems in a single problem format.

One of the topics in the magnetic, electrical course is electrostatic and electrodynamic. This material has characteristics of physic concepts that are abstract, microscopic, and difficult to understand (Mbonyiryivuze et al., 2019). Electrodynamic and electrostatic abstract concepts require some good intuitive and analytical capabilities to be visualized with multiple assistive media (Campos et al., 2019). The discovery of students at the university level in Athens has difficulty describing and analyzing electrostatic vectors of force (Stefanidou. et al., 2019). They have not defined microscopic to macroscopic concepts (Guisasola, 2014). One example in the initial observation, students look confused when asked about the idea of charge on persistent objects. In the completion process, they were mathematically able to complete calculations related to the total payload on the test load. Still, they could not argue the concept of the direction of the shipment on a 3-dimensional (3D) object. When further identified, some students responded in drawing and explained the direction of the charge on a 3dimensional plane. The problem happened because they do not have basic knowledge of related vector concepts in previous courses that became the basis of argumentation in explaining the idea of 3D models. Students can use several formats of image representation in outlining vectors of load components on a three-dimensional axis in the completion. Some of the above obstacles become obstacles in achieving the goals of achievement of lectures and understanding their concepts as prospective teachers who are competent in the field of teaching can be doubted by users.

Based on several indications of problems, the lecture must change a system in physics courses. The renewal of the learning system is not only in terms of material presentation but also in learning and evaluation into one unit. One of the considerations is the characteristics of physical materials that require qualitative and quantitative reasoning to understand. According to Carli et al. (2020), the proper method in presenting problems and the concept of physics quantitatively is multi-format representation. Visualization of issues through the representation format. That is the use of several presenter tools in expressing the idea of physics to be easily understood and explained. Some previous studies related to the use of representation formats in the teaching of physics (Nikat, 2018) described multi-representation assistance in problem-solving learning. Variations of the presentation presented in the representation format can develop students' creative thinking, the deepening of the concept of physics, and the suitability of ideas in solving physics problems (Velmovská, Kiss \& Trúsiková, 2019). Some of the representation formats that use solving physics are sketch formats of drawings, symbols, graphs, tables, diagrams, and mathematical equations. The form of use of the representation format is tailored to the needs and objectives. For example, the experiment results need to be presented in the form of diagrams or tables accompanied by verbal arguments. Therefore, by looking at the condition of the problem described, the author is interested in elaborating quantitative and qualitative descriptions of student argumentation skills in solving electrical topic problems.

\section{METHOD}

This study used a mixed-method research model with an embedded experimental design. The research subjects involved pre-service students of the Department of Physics Education, Musamus University. The participant takes the number of 32 students. Students got the treatment in the form of worksheet-assisted representation format in solving physics problems during the course. The primary purpose of presenting the representation format is to improve skills and familiarize students with solving physics problems by mature concepts with argumentation formulation. The design of the learning-assisted representation format is focused on solving physical problems related to daily 
application and fundamental concepts of electrical topics. The data collection of argumentation capabilities in this study using reasoned multiple-choice tests and interviews before and after the intervention.

The development of argumentation skill test instruments using five indicators of argumentation skill of 20 items test on electrical topics. The question instrument use validity and reliability test. The result of the validity test has ten items test on valid and the reliable at 0.634 value. This signifies a questionable instrument worthy of use in research. The question of argumentation skill is given before and after treatment to know how they help of representation format can help students improve their argumentation skills - the data obtained in quantitative and qualitative data. Data analysis techniques include quantitative data analysis using descriptive statistical analysis, prerequisite tests, t-paired tests, normalized gain scores, and effect size. Qualitative data analysis uses student answer grouping techniques in the form of coding the same answers. Several categories are obtained that vary about the level of student argumentation skill on electricity. The grouping of student answers was analyzed through the criteria of evaluation of argumentation skill adapted from Toulmin (2003) and adapted to a reasoned multiple-choice model. Tables 1 and 2 are groupings of arguments and materials for the development of argumentation capabilities.

Table 1. Student Argument skill Grouping Rubric

\begin{tabular}{lll}
\hline $\begin{array}{l}\text { Student Argumentation } \\
\text { Skill Category }\end{array}$ & \multicolumn{1}{c}{ Description } & Score \\
\hline Category 1 & $\begin{array}{l}\text { If Students did not use the concept correctly, it's backed } \\
\text { up by a false statement. The indication is that students } \\
\text { give answers and the wrong reasons }\end{array}$ & 1 \\
\hline Category 2 & $\begin{array}{l}\text { If Students did not answer correctly but can solve physics } \\
\text { problems correctly or provide appropriate reasons. The } \\
\text { indication is that students gave the wrong answer but } \\
\text { revealed the correct reason }\end{array}$ & \\
\hline Category 3 & $\begin{array}{l}\text { If Students can answer the question correctly but provides } \\
\text { a description or argument of the wrong solution. The } \\
\text { indication is that students give the correct answer, but the } \\
\text { reason given is incorrect or incomplete }\end{array}$ & \\
\hline Category 4 & $\begin{array}{l}\text { If a student meets the correct answer, the concept used is } \\
\text { right and the valid reason. }\end{array}$ & 4 \\
\hline
\end{tabular}

Table 2. Argumentation Skill Instrument Development Rubric

\begin{tabular}{lll}
\hline $\begin{array}{l}\text { Argumentation } \\
\text { Capability Indicator }\end{array}$ & \multicolumn{1}{c}{ Problem Indicators } & $\begin{array}{l}\text { Problem } \\
\text { Number }\end{array}$ \\
\hline Claims & $\begin{array}{l}\text { Students can deduce the relationship of charge type with } \\
\text { electrostatic force in certain phenomena }\end{array}$ & 1 \\
\cline { 2 - 3 } & $\begin{array}{l}\text { Students can analyze electrostatic style diagrams based on } \\
\text { interactions with multiple charges) }\end{array}$ & 3 \\
\hline Data & $\begin{array}{l}\text { Students can compare electrostatic force on two different } \\
\text { payloads based on the data of load quantity and style. }\end{array}$ & 4 \\
\cline { 2 - 3 } & $\begin{array}{l}\text { Based on data on the amount of charge and the number of } \\
\text { current strengths, students can identify the number of } \\
\text { electrons and the power of the current flowing on several } \\
\text { wires based on the concept of Kirchhoff law) }\end{array}$ & \\
\hline Warrant & Students can solve circuit-related problems in capacitors & 2,8 \\
\hline Backing & $\begin{array}{l}\text { Students can compare electrical potential at various points in } \\
\text { the conservative system }\end{array}$ & 7 \\
\cline { 2 - 3 } & $\begin{array}{l}\text { Students compared storage capacity on some examples of } \\
\text { circuits on parallel chip capacitors }\end{array}$ & 10 \\
\hline
\end{tabular}




\begin{tabular}{lll}
\hline Qualifier & $\begin{array}{l}\text { Students can identify the strength of currents and voltages } \\
\text { flowing in a series based on Kirchhoff equations }\end{array}$ \\
\cline { 2 - 3 } & $\begin{array}{l}\text { Students were able to find the amount of electrical charge } \\
\text { and the strength of the field flowing on a flowing wire based } \\
\text { on the equation of the order on the circular wire }\end{array}$ \\
\hline
\end{tabular}

Evaluation of argumentation skill criteria on each indicator is analyzed and determined by comparing the average score of each indicator with the maximum score. The criteria for argumentation are outlined in the form of percentages. Each of the comparison results is determined by the level of skill based on the table of score achievement criteria, which are as follows.

Table 3. Argumentation Capability Indicator Criteria

\begin{tabular}{cc}
\hline Percentage Score Range & Criteria \\
\hline $0 \leq x \leq 20$ & Very low \\
$21 \leq x \leq 40$ & Low \\
$41 \leq x \leq 60$ & Are \\
$61 \leq x \leq 80$ & High \\
$81 \leq x \leq 100$ & Very high \\
\hline
\end{tabular}

\section{RESULTS AND DISCUSSION}

Argumentation skill data is the pre-test and post-test answers of students. Argumentation capability data described based on the results of total score calculation pre-test and post-test data matching. Statistical data is used to answer the impact on students' argumentation skills before and after learning using problem-solving worksheets assisted by quantitative representation formats. Coding data is a qualitative description of the category of argumentation skill.

\section{Description of Student Argumentation Data Statistics}

Statistical descriptions contain quantitive calculations of students' argumentation skills. The statistical test includes prerequisite tests and advanced statistical tests on pre-test data and post-test argumentation capabilities. Prerequisite tests include normality and homogeneity tests to test the feasibility of data when advanced statistical tests are conducted. Normality test using Lilliefors test (Saphiro-Wilk). Homogeneity using Levene test and advanced statistical test using t-test paired sample. Advanced statistic tests are used to determine the effect of representation format-assisted worksheets in solving electrical concept problems. The following are the results of the normality and homogeneity tests of pre-test results and post-test problem-solving skills of learners in Table 4

Table 4. Description of Student Argumentation Ability Statistics Electrical Topics

\begin{tabular}{lccl}
\hline Data Description & Pre-test & Posttest & Data Conclusion \\
\hline Mean & 29,14 & 46,48 & There has been an increase in \\
\hline Standard Deviation & 4,81 & 9,82 & There is an Increase \\
\hline Minimum value & 25 & 35 & There has been an increase in \\
\hline Maximum value & 47,5 & 80 & There has been an increase in \\
\hline $\begin{array}{l}\text { Normality (Significance of } \\
\text { Shapiro Wilk) }\end{array}$ & 0.143 & 0.165 & Normally distributed data \\
\hline $\begin{array}{l}\text { Homogeneity (Significance of } \\
\text { Levene test) }\end{array}$ & 0.127 & Homogeneous Data \\
\hline N-gain test & & \\
\hline N-gain & 0.324 & Medium \\
\hline T-exhibit test & 4,23 & Strong \\
\hline & 0.000 & Significant differences \\
\hline
\end{tabular}

Based on table 3, There informed that the data of pre-test results and post-test of student argumentation skill has significant value with indications of homogeneous and normal data distribution. The data obtained will be normally contributed to the criteria if the significance value can be equal to or greater than 0.05 . The results obtained in this study showed the value of post-test and pre-test significance https://jurnal.unimus.ac.id/index.php/JPKIMIA/index 
is greater than (Pre-test data: $0.143>0.05$ and post-test data: $0.65>0.05$ ). Hence, the conclusion is that the pre-test and post-test data have a normal distribution of the population. Homogeneity test results showed a significance value of 0.159 for post-test data. It shows homogeneous pretest-posttest data $(0.127$ $>0.05)$. The influence of using worksheets assisted the format of representation in learning conducted by advanced statistical tests. Advanced statistical tests include the effect size test, N-gain test, and paired sample t-test test. All of them aim to describe an increase in student arguments before and after the intervention. The results of the analysis showed the calculation value of $\mathrm{N}$-gain earned 0.324 with a moderate category. The results showed that the improvement of students' argumentation skills before and after in the moderate category. The results of the effect size test showed a significance value of 4.23. the value indicated that the effect of providing worksheet-assisted representation format on electrical materials to the skill of argumentation students fall into the strong category (Kim. et al., 2007). The Ngain test calculation has a value of 0.509 with a moderate category. The calculation of paired t-tests explains that the hypothesis is accepted if the t-count value is less than or equal to 0.05 . The paired t-test calculations showed that the calculation value had a significance of $0.000<0.05$, so it can be concluded that there are significant differences in the argumentation skill of students before and after the intervention. In detail, the improvement of students' argumentation skills after obtaining worksheet training assisted by representation format can be seen in diagram 1 below.
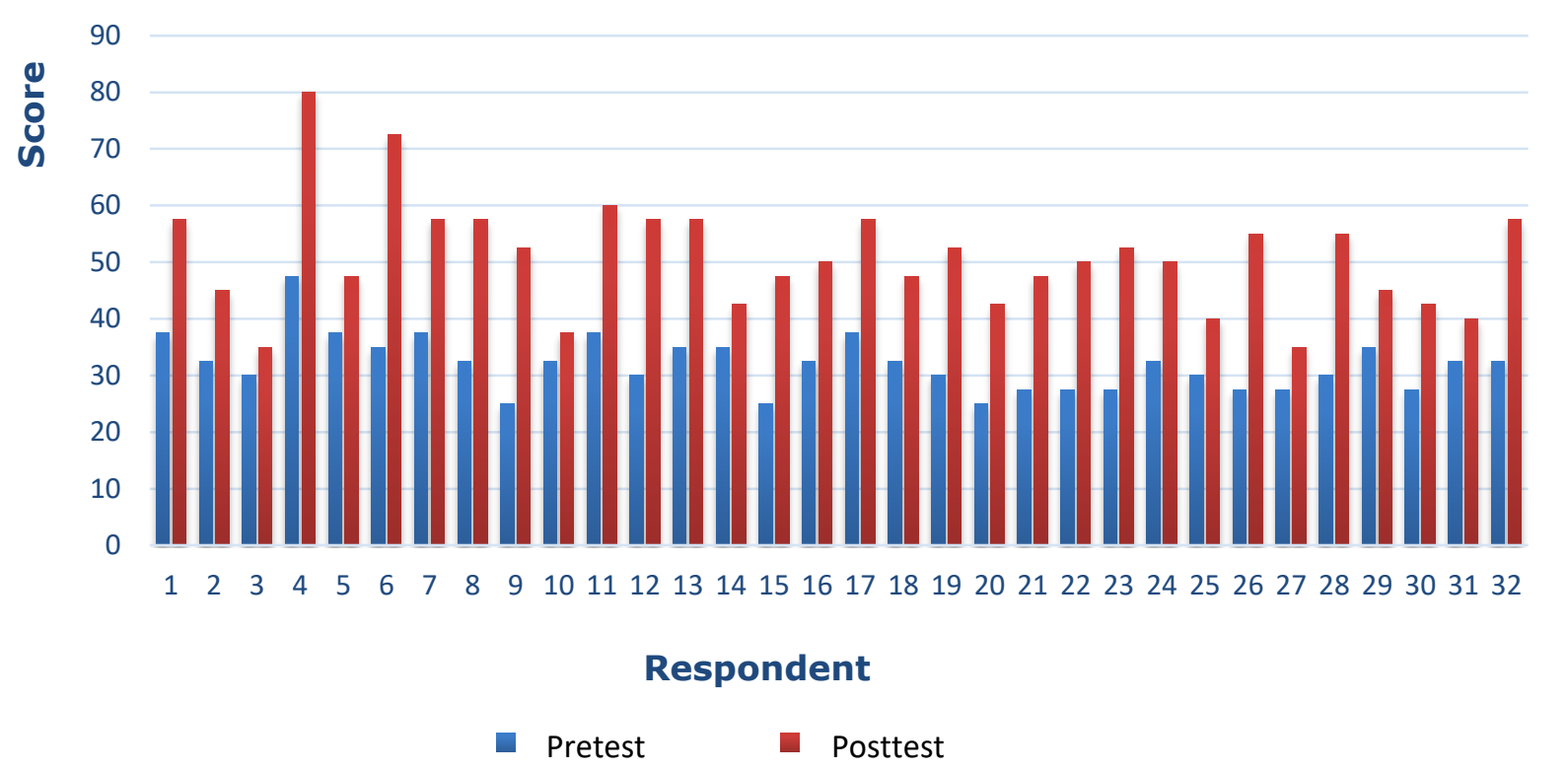

Figure 1. Graph of Changes in Students Argumentation skill on Electrical Topics

Graph number 1 showed that all of the students who get worksheet training assisted by representation format in solving physics problems could improve students' argumentation skills on electrical topics. This is proven based on the spread of the post-test value higher than the pre-test value. Some students look to be improving well, and some are only experiencing a slight improvement. The student of number 10 only experienced a slight increase in argumentation skill from pre-test to post-test. In contrast, students' numbers 4 and 6 showed a significant increase in the maturity of the pre-test and post-test. Student number 6 has the skill to argue both before and after treatment. Figure 2 showed the criteria for student argumentation skills on each indicator. 


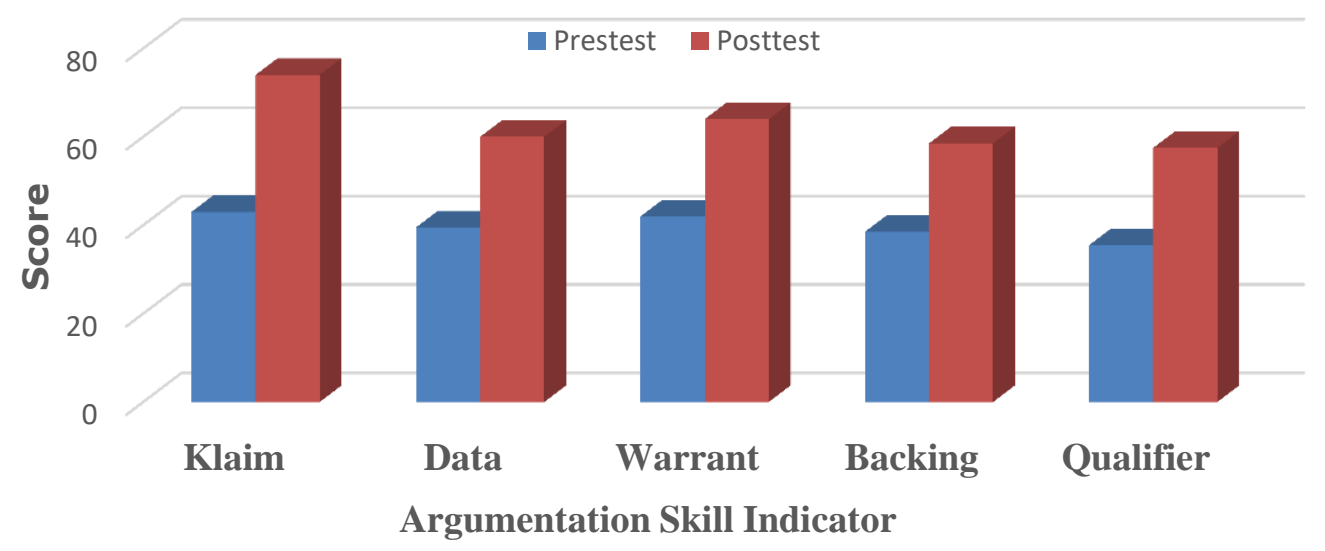

Figure 2. Graph of Changes in Student Argumentation Ability on Indicators

Based on Figure 2 showed a change in the average student's argumentation skill in each indicator. They are classifying each hand according to the criteria established in table 3 . The claim indicator shows a significant improvement, with indications that before the average treatment, students' skill only obtained a low category, then increased to a high type after receiving treatment. This indicates a significant influence on the implementation of worksheets assisted by the representation format in solving the problem of electrical concepts. The data indicator, warrant, backing, and qualifier show an increase from low to medium category. This showed that the average student majoring in physics education is still not maximally utilizing the help of several representation formats in improving the skill of argumentation. Lecturers need to study. Further, factors causing the increase are not very significant.

\section{Description of Student Argumentation Ability Category}

The category of argumentation skill in question is a qualitative and quantitative analysis of each indicator's level student's argumentation skill. The classification of student content ability category is divided into four levels, as stated in table 1. Based on the grouping results, the category of argumentation skill in each question, the average student is in categories 1 and 2 during pre-test and increased to category three during post-test. Figure 3 here is one example of a description of student answer changes at number 4 in answering problem number 1 with indicators of claims argumentation ability.

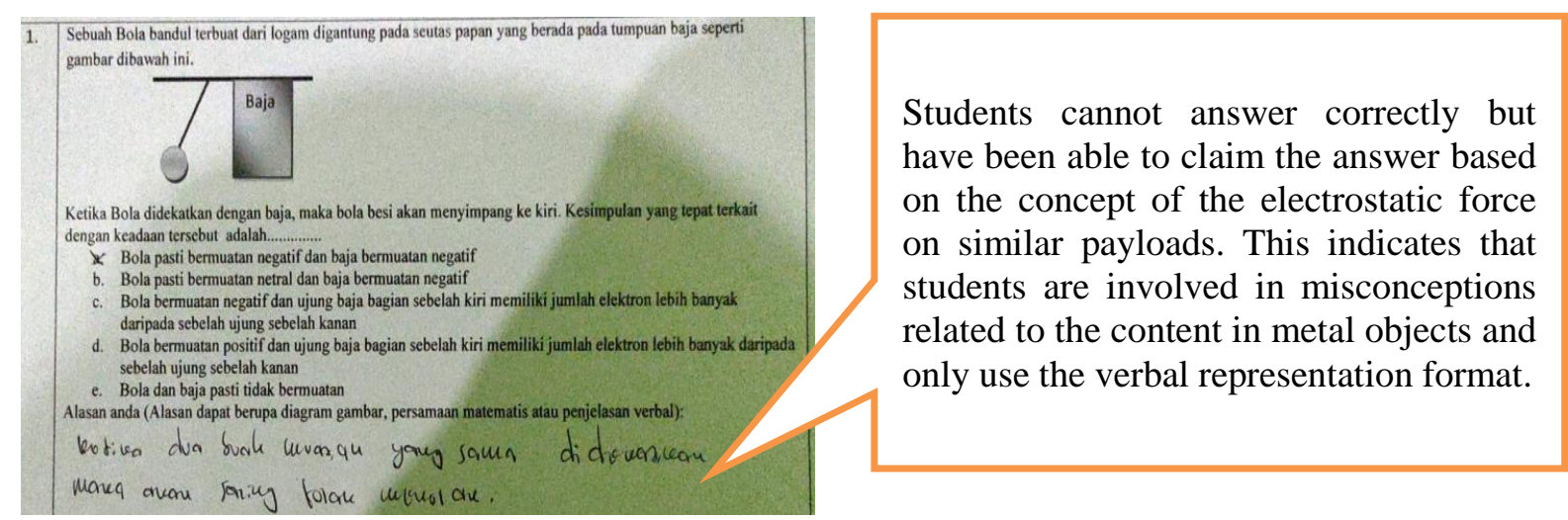

Figure 3a. Examples of Pretest Answers 


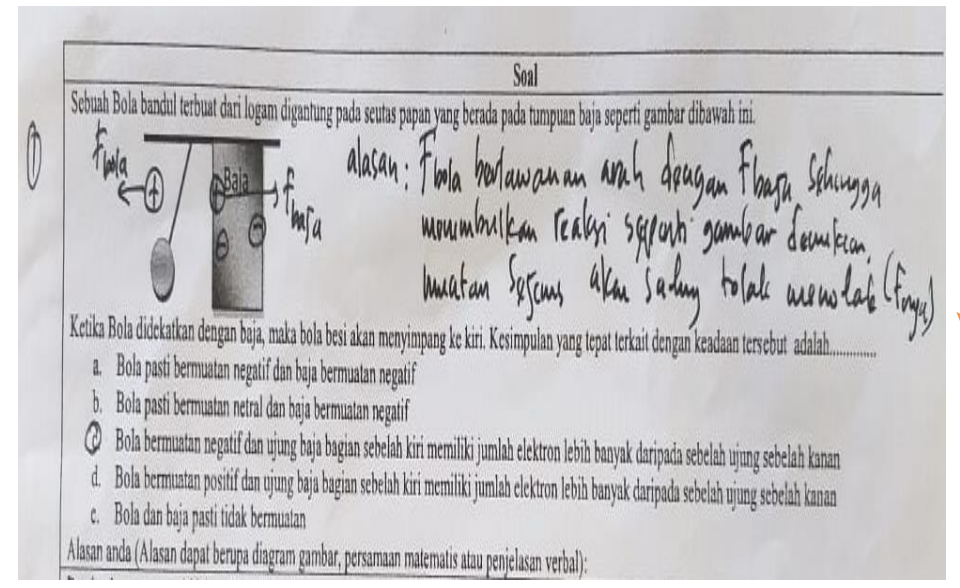

Students have been able to answer correctly and claim the answer based on the concept of the electrostatic force on a similar charge through the format of verbal representation and drawing sketches. This indicates that students have been able to use the correct concept in solving electrostatic force problems.

Figure 3b. Examples of Posttest Answers

Based on the sample, student answers in figures $3 \mathrm{a}$ and $3 \mathrm{~b}$ indicate a significant change in the student's argumentation skill in claiming the correct answer according to the concept of electrostatic force. Figure 4a shows that at first, the student had the skill to claim with category 2 , with indications that the student gave the correct reason for the concept of the electrostatic force on a similar charge. But when it comes to choosing the correct answer, students experience misconceptions about the component and interaction force of electrons, neutrons, and protons in metal materials. The majority of students chose the answer that steel must have only one charge, namely electrons, so the electrostatic force occurs only in both charges. Figure $4 \mathrm{~b}$ shows that the student has improved the skill of argumentation in claiming with category 4, with indications that the student has given the correct and logical reasons related to the concept of the electrostatic force on similar charges. After the treatment, Students have changed the idea that some content dominates on one end of the steel, accompanied by a verbal explanation or image visualization. Li \& Singh (2017) supported the discovery that most students have difficulty expressing the direction of electric force resultant, especially similarly charged ones. This is due to the inconsistency of students using multi-representation (Nousiainen \& Koponen, 2017)

Students' argumentation skills should be improved through a learning process that involves concrete experiences in learning activities. Improved argumentation skills can be done with various help that can interpret the concept of physics well and correctly. The concept of electricity is one of the materials with an abstract characteristic and microscopic nature, related to daily life, and its phenomena can be found in nature. Therefore, the learning method needs to visualize the abstract concept, be honest, and understand quickly. A combination can learn electrical materials of several detailed delivery methods. The skill of argumentation focuses on solving concrete problems and presenting the phenomenon of physic phenomena. The use of worksheets assisted by representation formats can direct lecturers and students in identifying the concept of essential concepts of physics as the basis for making claims, as a data source, and writing down theories or equations that support reason. The representation format consists of several studies tailored to the characteristics of electrical materials. The design of verbal representation can explain the relationship of several concepts in detail and systematically. Oral assistance can provide reasons for making a claim and warrant. The sketch representation of the image can explain the physical phenomena that occur in certain events. Image format assistance can make it easier to explain claims, warrants, and qualifiers. The format of equation representation can explain concepts through mathematical equations. The help of mathematical equations can decipher physical problems through mathematical equations so that conclusions can be drawn. In addition, students can use double representation in arguments. The integration of the dual model can help students identify the core keywords of the problem more fully and solve them with more public acceptance, science literacy, and argumentation (Bahri, 2012). 
The results of the student's post-test argumentation skill showed a more significant difference from the pre-test assessment. One example is the result of the concept of electrostatic force that increases from low to high category. The average pre-test results show that students have not been able to give arguments on all indicators. Based on the results of the interview, this kind of exercise is still relatively new for them. As one example, students can still not explain the basic concept of a similar charge electrostatic style on the phenomenon of deviation of conductor balls and steel. Average student answers answer by guessing or choosing solutions for incomplete reasons. After being given a worksheet assisted by the representation format, there is a change in the student's answer to the problem. They tend to use a dual representation format in conveying arguments well and correctly. This is evident in one of the answers that integrate image and verbal sketch representations in explaining the concept of electrostatic force. Another impact is also before the treatment. The majority of students have not been able to give arguments.

After the treatment, students can provide opinions with good quality. Some previous studies related to supporting the integration of representation formats can improve the skill of argumentation. Ismet (2017) revealed that the design of multi-representation learning in substance physics courses could develop the argumentation skills of prospective physics teachers. Dwiretno \& Setyarsih (2018) showed that the argumentation skill of future physics teachers is helpful as a provision to teach in schools and can be trained with models or learning methods relevant to the field of science. Argumentation exercises assisted by argumentative and representative models positively correlate to improving the understanding of physics concepts of students majoring in physics education (Amiroh \& Admoko, 2020). Improving the argumentation skill, teachers can organize the learning process through systematic and measurable student worksheets (Yusirana \& Siswanto, 2016). Therefore, the help of representation formats in lectures can be used even integrated into other models in improving the quality of argumentation, the quality of science literacy, and understanding of student concepts in solving physics problems

\section{CONCLUSION}

Based on the description of the results and discussion, it could be concluded that there is a significant influence of representation format assistance in improving student's argumentation skills. This is proven by the improvement of argumentation skill on all indicators, both qualitatively and quantitatively. Some representation formats can be used by students in solving physics problems following the truth of the concept of physics, so that the better the quality of problem-solving and science literacy. The more varied the representation assistance used, the better the quality of the student's argument. Variations of teaching models in lectures can be used as a tool of argumentation skills and understanding of student concepts. They did not have to experience misconceptions or errors in interpreting the concept of electricity. The long-term impact that arises is that students, as aspiring physics teachers, can teach the correct concepts of physics to their students.

\section{REFERENCES}

Amiroh, F., \& Admoko, S. 2020. Tinjauan Terhadap Model-Model Pembelajaran Argumentasi Berbasis TAP Dalam Meningkatkan Keterampilan Argumentasi dan Pemahaman Konsep Fisika Dengan Metode Library Research. Inovasi Pendidikan Fisika, 9(2).

Bahri, S. 2012. Penggunaan Multiplerepresetasi Dan Argumetasi Ilmiah Dalam Pembelajaran Fisika. Jurnal Serambi Ilmu, 13(1), 46-50.

Campos, E., Zavala, G., Zuza, K., \& Guisasola, J. 2019. Electric field lines: The implications of students' interpretation on their understanding of the concept of electric field and of the superposition principle. American Journal of Physics, 87(8), 660-667.

Cari, Pratiwi, S. N., Aminah, N. S., \& Nugraha, D. A. 2019. Analysis of student argumentation skills on static fluid topics. In AIP Conference Proceedings (Vol. 2202, No. 1, p. 020059). AIP Publishing LLC

Carli, M., Lippiello, S., Pantano, O., Perona, M., \& Tormen, G. 2020. Derivatives, Integrals, and Vectors in Introductory Mechanics: The Development of a Multi-representation Test for University Students. In Research and Innovation in Physics Education: Two Sides of the Same Coin (pp. 155-168). Springer, Cham 
Dwiretno, G., \& Setyarsih, W. 2018. Pembelajaran fisika menggunakan model Argument Driven Inquiry (ADI) untuk melatihkan kemampuan argumentasi ilmiah peserta didik. Inovasi Pendidikan Fisika, 7(2).

Guisasola, J. 2014. Teaching and learning electricity: The relations between macroscopic level observations and microscopic level theories. In: M. R. Matthews (Ed.), International handbook of research in history, philosophy and science teaching (pp.129-156). Dordrecht: Springer. doi:10.1007/978-94-007-7654-8_5

Ismet, I. 2017. Disain Model Multirepresentasi Pada Perkuliahan Pendahuluan Fisika Zat Padat untuk Mengembangkan Kemampuan Berargumentasi. In Seminar Nasional Pendidikan IPA (Vol. 1, No. 1, pp. 109-115)

Iwuanyanwu, P. N. 2019. Students' Understanding of Calculus-Based Kinematics and the Arguments They Generated for Problem Solving: The Case of Understanding Physics. Journal of Education in Science, Environment and Health, 5(2), 283-295.

Kim, S. H., Cohen, A. S., Alagoz, C., \& Kim, S. 2007. DIF detection and effect size measures for polytomous scored items. Journal of Educational Measurement, 44(2), 93-116.

Li, J., \& Singh, C. 2017. Investigating and improving introductory physics students' understanding of the electric field and superposition principle. European Journal of Physics, 38(5), 055702.

Mbonyiryivuze, A., Yadav, L. L., \& Amadalo, M. M. 2019. Students' conceptual understanding of electricity and magnetism and its implications: A review. African Journal of Educational Studies in Mathematics and Sciences, 15(2), 55-67.

Nousiainen, M., \& Koponen, I. T. 2017. Pre-Service Physics Teachers' Content Knowledge of Electric and Magnetic Field Concepts: Conceptual Facets and Their Balance. European Journal of Science and Mathematics Education, 5(1), 74-90.

Nikat, R. 2018. Kemampuan Pemecahan Masalah Dan Berpikir Kritis Melalui Strategi Problem Solving Berbantuan Multirepresentasi Pada Materi Usaha Dan Energi. DISERTASI dan TESIS Program Pascasarjana UM

Öztürk, A., \& Doğanay, A. 2019. Development of Argumentation Skills through Socioscientific Issues in Science Course: A Collaborative Action Research. Turkish Online Journal of Qualitative Inquiry, 10(1).

Sinaga, P. 2014. Pengembangan program perkuliahan fisika sekolah iii untuk meningkatkan kompetensi menulis materi ajar calon guru menggunakan multi modus representasi (Doctoral dissertation, Universitas Pendidikan Indonesia).

Stefanidou, C. G., Tsalapati, K. D., Ferentinou, A. M., \& Skordoulis, C. D. 2019. Conceptual Difficulties Pre-Service Primary Teachers Have with Static Electricity. Journal of Baltic Science Education, $18(2), 300$

Toulmin, S. E. 2003. The uses of argument. Cambridge University Press.

Trilling, B., \& Fadel, C. 2009. 21st-century skills: Learning for life in our times. John Wiley \& Sons.

Velmovská, K., Kiss, T., \& Trúsiková, A. 2019. Critical thinking and physics education. In AIP Conference Proceedings (Vol. 2152, No. 1, p. 030037). AIP Publishing LLC.

Viyanti, V., Cari, C., Sunarno, W., \& Prasetyo, Z. K. 2016. Pemberdayaan Keterampilan Argumentasi Mendorong Pemahaman Konsep Siswa. Jurnal Penelitian Pembelajaran Fisika, 7(1), 43-48.

Viyanti, V., Cari, C., Sunarno, W., \& Prasetyo, Z. K. 2020. Reconstructing of Higher Order Thinking Skills through Enriching Student's Argumentation Skills. Jurnal Pendidikan Progresif, 10(2), 327-335.

Yusiran, Y., \& Siswanto, S. 2016. Implementasi Metode Saintifik Menggunakan Setting Argumentasi pada Mata Kuliah Mekanika untuk Meningkatkan Kemampuan Kognitif Mahasiswa Calon Guru Fisika. Jurnal Penelitian \& Pengembangan Pendidikan Fisika, 2(1), 15-22 